\title{
Editorial
}

\section{Is place branding a capitalist tool?}

A crisis of conscience - or perhaps it is fairer to call it a mood of reflection has gripped the development community. Of course there have always been voices questioning the basic assumptions of economic growth (whether it really confers all the benefits it is intended to; whether it really helps the poor or simply increases the wealth gap; whether it is a suitable model for all countries, irrespective of size, culture, religion, values, aspirations and so forth), but the reflections seem to be growing more intense by the year.

Today, the difficult questions about development are no longer dismissed as irritating interruptions to the great project of universal economic growth, made by the economically naive or the politically biased. Joseph Stiglitz's thoughtful review of Benjamin Friedman's 'The Moral Consequences of Economic Growth' in the latest edition of Foreign Affairs presents us with the fascinating spectacle of world-class economists vying with each other to be perceived as more moral, more culturally sensitive and more versed in 'soft' values. Most interestingly, the question of happiness has begun to emerge in these debates, partly stimulated by HM Jigme Singye Wangchuck, the King of Bhutan, and his notion of 'gross national happiness' as an alternative to GDP. $\mathrm{He}$ argues that, while his people are indubitably poor and could benefit from increased financial wealth, they are not unhappy, and there is a risk that participating in the global economy will diminish their contentment and perhaps not even improve their material well-being in any predictable, sustainable or even-handed way.

The idea that economic development might not be a panacea - or that, as our parents told us, money might not buy us happiness - is one of the most important to emerge from the development and globalisation debate. Consumerism is, without doubt, an incurable disease, and most readers in rich or developing countries will know the ache of wanting and wanting a particular possession, at last buying it and then feeling the same emptiness gradually return a few days or weeks later. On a recent visit to Bhutan I was struck by the impression that this is a society in the last days of its innocence, where the endless cycle of returning emptiness is still fairly unfamiliar. There are needs, but there appear to be relatively few desires.

Of course, place branding is implicated in the discussion. I have often described the notion of place branding for economic development as a means of 'hacking' one of the first world's most potent and effective tools of wealth creation (after all, brand value, according to some accounts, may represent as much as one-third of all the wealth on the planet) and pressing it into the service of the countries which most need growth. But the wisdom of taking a capitalist tool like branding and applying it to developing countries must be closely questioned — and good intentions, while 
they go a long way, are not adequate to ensure that the benefits brought are indeed benefits to all, or that they will prove beneficial in the longer term. A Buddhist would insist that for this or any process to be a benign one, it must do no harm to any person (whether within the country itself, or as an 'externality' in other parts of the world), to any sentient being, to nature or to future lives. In other words, it is not sufficient to be a good neighbour: one must also be a good ancestor.

Branding, like any other tool, is itself ethically neutral: it is the use to which the tool is put that determines whether it complies with such strictures or not. I would argue that considerations like these should form an essential part of the criteria by which any national branding strategy is judged, but they are not a reason why nation branding itself should not be practised.

After all, the alternative to 'doing' nation branding is not not doing nation branding: the alternative is allowing others to do the branding for you. Nation branding is, as I have remarked before, as much self-defence as proactive behaviour: it is the necessary response to (or, in the case of Bhutan, the prudent protection against) the naturally trivialising tendency of international public opinion. As long as public opinion matters - and it matters terribly, because the public is the market - then it is not only legitimate but also vital for countries to do whatever is in their power to ensure that public opinion is as fair, as accurate and as positive as it possibly can be. Countries which do not do this run the risk of being saddled with a brand which does not suit their aims or interests at all, and which is very likely based on ignorance, hearsay, confusion or long-past events.

I have always held that the market-based view of the world, on which the theory of place branding is largely predicated, is an inherently peaceful and humanistic model for the relationships between nations. It is based on competition, consumer choice and consumer power; and these concepts are intimately linked to the freedom and power of the individual. For this reason, it seems far more likely to result in lasting world peace than a statecraft based on territory, economic power, ideologies, politics or religion.

In a world dominated by the capitalist system, it is easy to conclude that real competitive advantage can only come from economic, political or military strength - and the unending emphasis on GDP is at the heart of this conception. But, as in any busy marketplace, there is room on the global stage for brands which play by slightly different rules; there is room for niche brands, and room for brands which compete primarily on cultural excellence rather than on economic muscle.

Bhutan might, in strictly productive terms, be too small even to be viable as an independent state in the long term, but its real primacy lies in other areas: in its unspoilt landscape, the stability of its social model, its culture and heritage, the wisdom and world view of its people. Any system which is capable of registering and recognising such factors as having negotiable value - indeed, as the components of competitive advantage is surely worth particular consideration; and since brands are made from values, there is no reason why countries like Bhutan should not benefit from a brand which is considerably greater than the size of their economies, land areas or populations would suggest. Economies gain no advantage from being small economies; armies gain no advantage from being small armies; but the small size of a nation like Bhutan can represent a real branding advantage — to be small, 
unique, even fragile, confers a certain precious quality to the nation brand which big countries can only envy.

And even if the brand image of the country is made of cultural rather than economic factors - even if it is famous for a wealth which is decidedly non-monetary - this still enables it to 'punch above its weight' in world affairs, and enjoy an influence which is out of proportion to its GDP. What it chooses to do with that influence is of course its own business, but should economic growth be the ultimate aim then, as every marketer knows, owning a famous brand is the best possible precursor to building a profitable business. Why else would companies like Google or Skype gamble profit for profile, and why should the marketplace rate their intangible assets - their brand values and customer relationships - far above any

conventional criteria of financial viability? What really counts is having a hold over the imagination of the customer - a unique and appealing proposition which represents a licence to do business with that customer. Countries like Bhutan have this kind of imaginative power in abundance and, once harnessed, can use it to leverage whatever economic, social, political or cultural advances they choose.

One of the great inequalities in the world is the fact that the richer countries have higher brand profiles than the poorer countries. This is because they have more access to the media, because they tend to export more products and services (which act as particularly powerful ambassadors of national image), because their people travel more freely and thus represent the country more widely and for a whole host of other reasons. This unequal distribution of brand power is well illustrated by the results of the Anholt-GMI Nation Brands Index, in which all of the nations which are highly ranked by GMI's panel of around 18,000 ordinary consumers in 18 countries (both rich and developing) are also the wealthiest nations. This fact ensures that the huge discrepancy between their fortunes and those of the poorer nations is a robust and durable phenomenon - because competing is twice as hard with a weak or negative brand image than it is with a strong one.

As I observed in my Foreword to the third issue of Place Branding, a country with a poor brand often finds that the world's media will react with cynicism or indifference to its most enlightened actions and communications, while countries with strong brands seem to have little trouble gaining respect and attention for their most mediocre pronouncements. Countries with powerful and positive reputations find it easier, cheaper and faster to attract foreign investment and talent, tourists and consumers and to gain the respect and interest of the world's media. Poorer countries, with weaker or less positive brand images, find all of these actions to be considerably more of an uphill struggle.

Many poor countries have, in effect, no international brand image at all (although of course every place, even the tiniest village, has a brand, at least as far as its nearest neighbours are concerned) and thus find themselves considerably disadvantaged in the global economy: they are, in effect, products without packaging in the global supermarket. Such countries generally end up sharing their reputation - often unfairly and inaccurately — with the most prominent and most infamous countries in their continent. This syndrome, which I call 'continent branding effect', where the worst attributes of the least progressive country in a continent tend to be ascribed to every country in that continent, is discussed in more detail in the report on the first Anholt-GMI City 
Brands Index which is published in this issue of Place Branding.

It is one of the most challenging and important roles of place branding to ensure that unbranded states are able to compete on more equal terms with the thoroughly branded, and, as far as possible, to level the playing field. In the struggle for competitive advantage in the modern world, the factor of national brand image is becoming more and more significant, and the sooner that the development 'community' recognises that perception is as important as reality in the global marketplace, the better its assistance will match the real needs of the countries it aims to help.

\section{Simon Anholt Managing Editor}

